\title{
TEACHERS' VIEWS ON STUDENTS' PERFORMANCE IN ENGLISH LANGUAGE PROFICIENCY COURSES VIA CEFR DESCRIPTORS
}

\author{
Ramiaida Darmi ${ }^{1 *}$, Noor Saazai Mat Saad ${ }^{2}$, Norhana Abdullah $^{3}$, Fariza Puteh-Behak ${ }^{4}$, \\ Zarina Ashikin Zakaria ${ }^{5}$, Juliana Niza Ismail Adnan ${ }^{6}$ \\ ${ }^{1}$ Dr., Universiti Sains Islam Malaysia, MALAYSIA, ramiaida@usim.edu.my \\ ${ }^{2}$ Dr., Universiti Sains Islam Malaysia, MALAYSIA, noorsaazai@usim.edu.my \\ ${ }^{3}$ Ms., Universiti Sains Islam Malaysia, MALAYSIA, norhana@usim.edu.my \\ ${ }^{4}$ Dr., Universiti Sains Islam Malaysia, MALAYSIA, fariza@usim.edu.my \\ ${ }^{5}$ Ms., Universiti Sains Islam Malaysia, MALAYSIA, zarina@usim.edu.my \\ ${ }^{6}$ Ms., Universiti Sains Islam Malaysia, MALAYSIA, juliana@usim.edu.my \\ ${ }^{*}$ Corresponding author
}

\begin{abstract}
'The English Language Education in Malaysia: An Agenda for Reform 2015-2025' is a blueprint initiated by The Ministry of Education (MOE), Malaysia, currently launched in 2016. The key pledge to this blueprint is the alignment of Malaysia's English Language Education System with the Common European Framework of Reference for Languages (CEFR). CEFR is a benchmark for an international standard that focuses on developing learners who are able to communicate and interact in any language, in this instance, English. The focal point of the Malaysian education reform is to adopt the CEFR levels as the guiding beacon or regulating framework for curriculum development, issues regarding learning materials and the measurement of learning outcomes. In keeping with this reform, the study aims to understand English language teachers' views on the English language proficiency courses in a local university, in Malaysia, based on CEFR scales. The study employs a quantitative approach, where surveys were distributed to twenty-five English language teachers. The data is then analysed quantitatively by frequency counts and percentage. Data shows there are variations in teachers' views towards English language proficiency courses, and this may not necessarily fit into the CEFR standards targeted for university learners. The result of this study acts as preliminary data for further research on the link between English language course content and CEFR standards, as well as expected English language proficiency of university learners. Through this study, it is hoped that future design of teaching and learning materials that contribute to 'proficient' learners at the end of university years, can be developed.
\end{abstract}

Keywords: Common European Framework of Reference (CEFR), teaching and learning, language proficiency, English language curriculum. 


\section{INTRODUCTION}

Educational transformation in Malaysia has gone through many changes due to development of the country and economic growth. The current education transformation is highlighted in the 2013-2025 Education Development Plan (Pelan Pembangunan Pendidikan, 2012). One of the measures is related to the use of language in the teaching and learning process. In the domain of education in Malaysia, English language is used in many ways. It is the lingua franca of education, language of communication, language of instruction and language in the academic world. However, some students still treat English as a foreign language, which result in their inability to be fluent in the language at the end of their school years. In addition, some regard English as unimportant as it is not a required pass subject. Nevertheless, English maintains its position as a world language in business and science, and for that reason will remain popular as one of the languages of educated Malaysian citizens.

The concern among tertiary students' level of English language proficiency is related to the marketability or employability rate of Malaysian graduates. This is due to the fact that many studies have shown that one of the main sources of unemployability among graduates is failure to communicate in English and Malay (Nik, Azmi, Rusyda, Arena, \& Khairani, 2012). This, it is the aim of the Ministry to achieve the main objective of the country, that is for graduates to achieve the required level of proficiency for employability purpose. Thus, this study takes a step forward by exploring the current English language roadmap launched by the Ministry of Education, Malaysia, and teachers' views on their students' performance in the existing English language courses in universities. This is important as it prepares the university and teachers on what changes they might need to make in the English language courses so that the aims of the ministry to produce citizens who are proficient in English language can be achieved.

\subsection{English language education in Malaysia: its reform}

The language goal for Malaysia's education system is to "ensure every child is proficient in Bahasa Malaysia and English language and is encouraged to learn an additional language" (Malaysia Education Blueprint 2013-2025, E-12). To support this goal, the Ministry of Education (MOE), Malaysia, has launched its blueprint "English Language Education Reform in Malaysia: The Roadmap 2015-2025". In this blueprint, the Common European Framework of Reference for Languages (henceforth "CEFR") is being adopted by countries across the globe, to the extent that it has become de facto the international standard (English Language Education Reform in Malaysia: The Roadmap 2015-2025, 2016, p. 5).

Based on the Malaysian Education Plan, there are seven out of eleven shifts that are relevant to English language education - Shift 1, 2, 4, 5, 7, 9 and 10 - which calls for an alignment of the English language curriculum and assessment to the CEFR. In 2013, a Cambridge Baseline study was conducted to evaluate the current state of English teaching and learning in Malaysia based on CEFR. It assessed the proficiency of samples of students from pre-school to post-secondary education, and also English language teachers. The benchmark shows the current performance in Malaysia in relation to other countries. It was found that "although our current system may be sufficient for the needs of the past, it is not at all sufficient for us to succeed as a nation in a globalised world that requires English for international communication of all kinds" (The Roadmap, p. 8). The roadmap highlights the national agenda that sets the overall target for English language programme in the production of school leavers and graduates with the level of English proficiency they need to make themselves employable in the modern globalised world.

\subsection{Common European Framework of Reference (CEFR)}

The key to the road map is the alignment of Malaysia's English Language Education System with CEFR an international standard that focuses on producing learners who can communicate and interact in any language, in this instance, English. A key element of the education reform is to adopt the CEFR levels as the governing framework for curriculum development, selection of learning materials and measuring learning outcomes. CEFR is developed by the Council of Europe. It provides a general framework which indicates what language learners need to learn to be able to use a foreign language effectively in practice. The CEFR "provides a common basis for the elaboration of language syllabuses, curriculum guidelines, examinations, textbooks, etc. across Europe. It describes in a comprehensive way what language learners have to learn to do in order to use a language for communication and what knowledge and skills they have to develop to be able to act effectively (Hamidah Yamat, Nur Farita Mustapa Umar \& Muhammad llyas Mahmood, 2014). The framework also defines the proficiency levels that allow learners' progress to be measured at each stage of learning and on a life-long basis" (Council of Europe, 2001, p. 1). It provides comprehensive views of what people can do with language, and seems to be very useful in setting truly communicative, functional goals for learners. 
The CEFR distinguishes five communication skills, namely listening, reading, spoken interaction, spoken production, and writing. Language proficiency is measured in relation to the five skills on a scale beginning with $A 1$, and progressing through $A 2, B 1, B 2$ and $C 1$ to $C 2$. Proficiency in each skill is defined at each level by a series of "can do" statements (see Table 1 ).

Table 1: CEFR Descriptors

\begin{tabular}{|c|c|c|}
\hline USER & LEVELS & ESCRIPTORS \\
\hline \multirow[t]{2}{*}{$\begin{array}{c}\text { A } \\
\text { English } \\
\text { Basic } \\
\text { User }\end{array}$} & $\begin{array}{c}\text { A1 } \\
\text { Beginner }\end{array}$ & $\begin{array}{l}\text { Can understand and use familiar everyday expressions and very basic } \\
\text { phrases aimed at the satisfaction of needs of a concrete type. Can } \\
\text { introduce him/herself and others and can ask and answer questions } \\
\text { about personal details such as where he/she lives, people he/she } \\
\text { knows and things he/she has. Can interact in a simple way provided } \\
\text { the other person talks slowly and clearly and is prepared to help. }\end{array}$ \\
\hline & $\begin{array}{c}\text { A2 } \\
\text { Elementary } \\
\text { English }\end{array}$ & $\begin{array}{l}\text { Can understand sentences and frequently used expressions related to } \\
\text { areas of most immediate relevance (e.g. very basic personal and } \\
\text { family information, shopping, local geography, employment). Can } \\
\text { communicate in simple and routine tasks requiring a simple and direct } \\
\text { exchange of information on familiar and routine matters. Can describe } \\
\text { in simple terms aspects of his/her background, immediate environment } \\
\text { and matters in areas of immediate need. }\end{array}$ \\
\hline \multirow[t]{2}{*}{$\begin{array}{c}\text { B } \\
\text { English } \\
\text { Independent } \\
\text { User }\end{array}$} & $\begin{array}{c}\text { B1 } \\
\text { Intermediate } \\
\text { English }\end{array}$ & $\begin{array}{l}\text { Can understand the main points of clear standard input on familiar } \\
\text { matters regularly encountered in work, school, leisure, etc. Can deal } \\
\text { with most situations likely to arise whilst travelling in an area where } \\
\text { the language is spoken. Can produce simple connected text on topics } \\
\text { which are familiar or of personal interest. Can describe experiences } \\
\text { and events, dreams, hopes \& ambitions and briefly give reasons and } \\
\text { explanations for opinions and plans. }\end{array}$ \\
\hline & $\begin{array}{c}\text { B2 } \\
\text { Upper- } \\
\text { Intermediate } \\
\text { English }\end{array}$ & $\begin{array}{l}\text { Can understand the main ideas of complex text on both concrete and } \\
\text { abstract topics, including technical discussions in his/her field of } \\
\text { specialisation. Can interact with a degree of fluency and spontaneity } \\
\text { that makes regular interaction with native speakers quite possible } \\
\text { without strain for either party. Can produce clear, detailed text on a } \\
\text { wide range of subjects and explain a viewpoint on a topical issue } \\
\text { giving the advantages and disadvantages of various options. }\end{array}$ \\
\hline \multirow[t]{2}{*}{$\begin{array}{c}\text { C } \\
\text { Proficient } \\
\text { English } \\
\text { User }\end{array}$} & $\begin{array}{c}\text { C1 } \\
\text { Advanced } \\
\text { English }\end{array}$ & $\begin{array}{l}\text { Can understand a wide range of demanding, longer texts, and } \\
\text { recognise implicit meaning. Can express him/herself fluently and } \\
\text { spontaneously without much obvious searching for expressions. Can } \\
\text { use language flexibly and effectively for social, academic and } \\
\text { professional purposes. Can produce clear, well-structured, detailed } \\
\text { text on complex subjects, showing controlled use of organisational } \\
\text { patterns, connectors and cohesive devices. }\end{array}$ \\
\hline & $\begin{array}{c}\mathrm{C} 2 \\
\text { Proficiency }\end{array}$ & $\begin{array}{l}\text { Can understand with ease virtually everything heard or read. Can } \\
\text { summarise information from different spoken and written sources, } \\
\text { reconstructing arguments and accounts in a coherent presentation. } \\
\text { Can express him/herself spontaneously, very fluently and precisely, } \\
\text { differentiating finer shades of meaning even in more complex } \\
\text { situations. }\end{array}$ \\
\hline
\end{tabular}

This scale enables the ministry to set targets for each stage of the English language programme. The targets set to be achieved by 2025 for Malaysian students to reach as they progress through the English language programme is shown in Figure 2. In the context of English language proficiency, this means that between now and 2025, the ministry expects an increasingly large proportion of Malaysian students from all social backgrounds to achieve the target proficiency level expressed in terms of the CEFR set for each stage of education (English Language Education Reform in Malaysia: The Roadmap 2015-2025, 2016, pp. 5-6). 


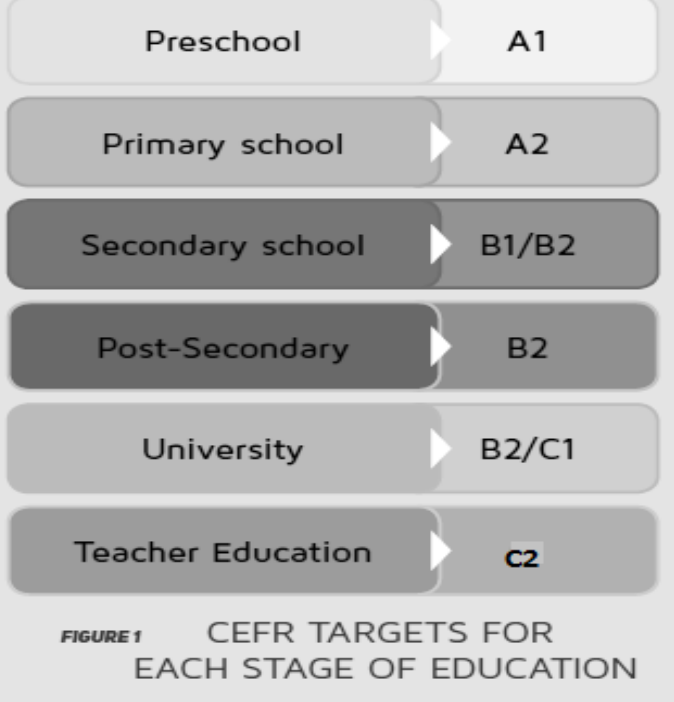

Figure 1: CEFR Targets

As Malaysia is very rapidly internationalizing, particularly in the field of education, the Ministry of Education, Malaysia has taken the decision of involving CEFR in language education, mainly to scale its students' language abilities against globally acknowledged levels. The framework is able to support the language syllabuses and curriculum guidelines, the design of teaching and learning materials, and the assessment of foreign language proficiency.

\subsection{Significance of the study}

With the country's effort to transform language education in Malaysia, this study hopes to shed some light into the implementation of CEFR into our English language education system. More exploration and understanding are required into CEFR and how it should be used at the tertiary level. This is important as English language at tertiary level is at Phase 2 of the roadmap (2017-2020) and MEB waves 1-3 (20132025). Therefore, with the advancement in the international language arena where the mapping of CEFR has been done against the world-recognised courses and tests in providing "a mutual recognition of qualifications gained in different learning contexts" (Council of Europe, 2001, p. 1), there is a need to look at the roadmap and understand how CEFR should be used to align to the English language curriculum in higher education. In supporting this, this study takes a beginning step in looking at the English language courses in a selected local university in Malaysia and how its current students' performance fits into CEFR scales. It is significant to use CEFR as a globally-accepted framework; thus, aligning the English language courses to students' performance in relation to CEFR shows the initiative of moving towards the English education reform in Malaysia.

\subsection{Purpose of the paper}

Since the English Language Education Reform in Malaysia 2015-2025 was launched, the ministry has made it compulsory for all English language teachers in universities to undergo its CEFR familiarisation trainings. This is to inform and expose them to CEFR and its use for English language education. In relation to that, there is a need to explore the existing English language proficiency courses at a local university, and how the teachers involved link the course content to CEFR. This would hopefully provide input for the revision of the course content to align with CEFR in the future. Thus, this paper aims at gathering teachers' views on students' performance in the existing English language courses based on the global CEFR descriptors.

\section{METHODOLOGY}

Using a quantitative approach, the study involved twenty-five English language teachers who teach English proficiency courses in the current semester. Participants were given an online survey that investigated their views on their students' English language performance in the English language class. The survey consisted of 23 statements, which were adapted from the descriptive scales provided by Council of Europe's 'Common European Framework of Reference for Languages: Learning, teaching, assessment - Structured overview of all CEFR scales'. The survey required participants to evaluate the statements based on a 5-point Likert scale - scale 1 as 'strongly disagree' to scale 5 as 'strongly agree'. The data were then transferred into graphs and percentage. This was then aligned to the CEFR B2 target (refer to Figure 2) and its descriptors (refer to 
Table 1) as it is the target aimed for university students.

Overall, there are five levels of English proficiency courses in the university (refer to Table 2). However, students are only required to complete at least three levels of English proficiency courses throughout their candidature.

Table 2: English proficiency courses in the university

\begin{tabular}{|c|c|c|c|c|c|}
\hline \multirow[t]{2}{*}{ Level } & \multirow{2}{*}{\multicolumn{2}{|c|}{ Course }} & \multicolumn{3}{|c|}{ MUET Band } \\
\hline & & & $1 / 2$ & 3 & 4 \\
\hline 1 & \multicolumn{2}{|l|}{ General English Proficiency } & $\sqrt{ }$ & & \\
\hline $1 / 2$ & \multicolumn{2}{|c|}{ English for Communicative Purposes } & $\sqrt{ }$ & $\sqrt{ }$ & \\
\hline $1 / 2 / 3$ & \multicolumn{2}{|l|}{ English for Academic Purposes } & $\sqrt{ }$ & $\sqrt{ }$ & $\sqrt{ }$ \\
\hline \multirow[t]{5}{*}{$2 / 3$} & \multirow{5}{*}{$\begin{array}{l}\text { English for Specific } \\
\text { Purposes } \\
\text { (based on faculty) }\end{array}$} & English for Science \& Technology & & \multirow{5}{*}{$\sqrt{ }$} & \multirow{5}{*}{$\sqrt{ }$} \\
\hline & & English for Professionals & & & \\
\hline & & English for Business \& Commerce & & & \\
\hline & & English for Legal Professionals & & & \\
\hline & & $\begin{array}{l}\text { English for Medical \& Health } \\
\text { Professionals }\end{array}$ & & & \\
\hline 3 & \multicolumn{2}{|l|}{ English for Research Purposes } & & & $\sqrt{ }$ \\
\hline
\end{tabular}

Table 2 shows that students are allocated into English language classes based on their Malaysian University English Test (MUET) result, which are in the form of band score. MUET is a competency test which aims to measure the English language proficiency of pre-university learners for entry into tertiary education (Malaysian Examinations Council, 2006). Based on their MUET result, students are allocated to their English language class, the complete levels for English language class is three (3) levels.

\section{FINDINGS}

The online survey was distributed to thirty English language teachers, however, only twenty-five responded to the survey. These twenty-five participants consisted of teachers who taught at least one of the English language courses listed. The highest number of participants who responded were teachers who taught English for Academic Purposes (EAP), with a 44\% response rate, followed by English for Communicative Purposes (ECP), with a $32 \%$ response rate (refer to Figure 3 ). This is followed by others - English for Science and Technology (EST), English for Business and Commerce (EBC), English for Medical and Health Professionals (EMHP) and English for Research Purposes (ERP) - with a 16\% response rate, and lastly General English Proficiency (GEP) with an 8\% response rate.

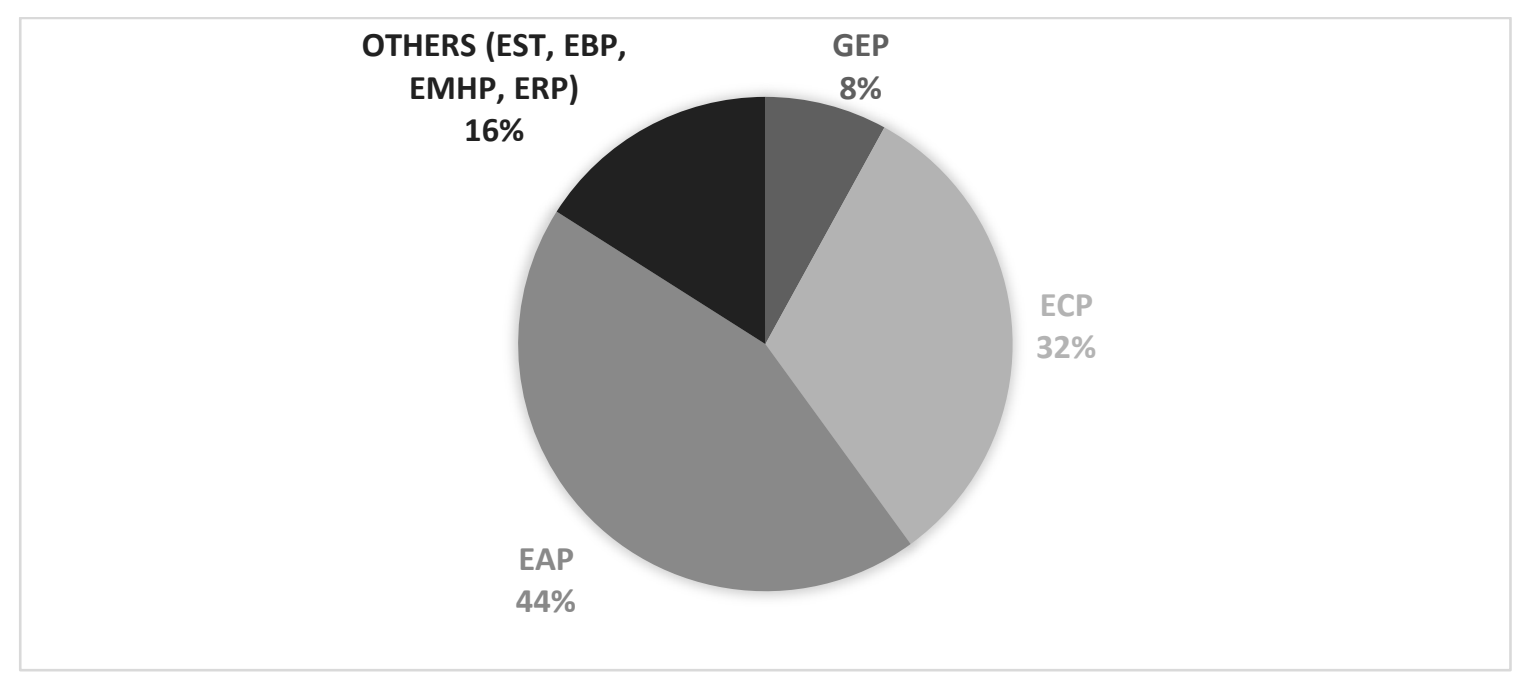

Figure 2: Number of responses based on course

The online survey consists of statements taken from level B2 of the CEFR global scale. These statements were separated into four items. For each item, participants had to choose a scale to show their overall view of their students' ability to the 'can do' statements provided.

In item 1, participants had to view whether their students can 'understand the main ideas of complex text on both concrete and abstract topics including technical discussions in his/her field of specialisation'. This item 
relates to reading skill. The data (refer to Figure 3 ) show that only $28 \%$ (from scale $4 \& 5$ ) of the participants strongly agreed and agreed, while $44 \%$ opted to disagree and agree with item 1, and another $28 \%$ (from scale 1 \& 2) disagreed and strongly disagreed. This shows that overall, for reading comprehension, not many tudents have managed to achieve clear understanding of a variety of texts.

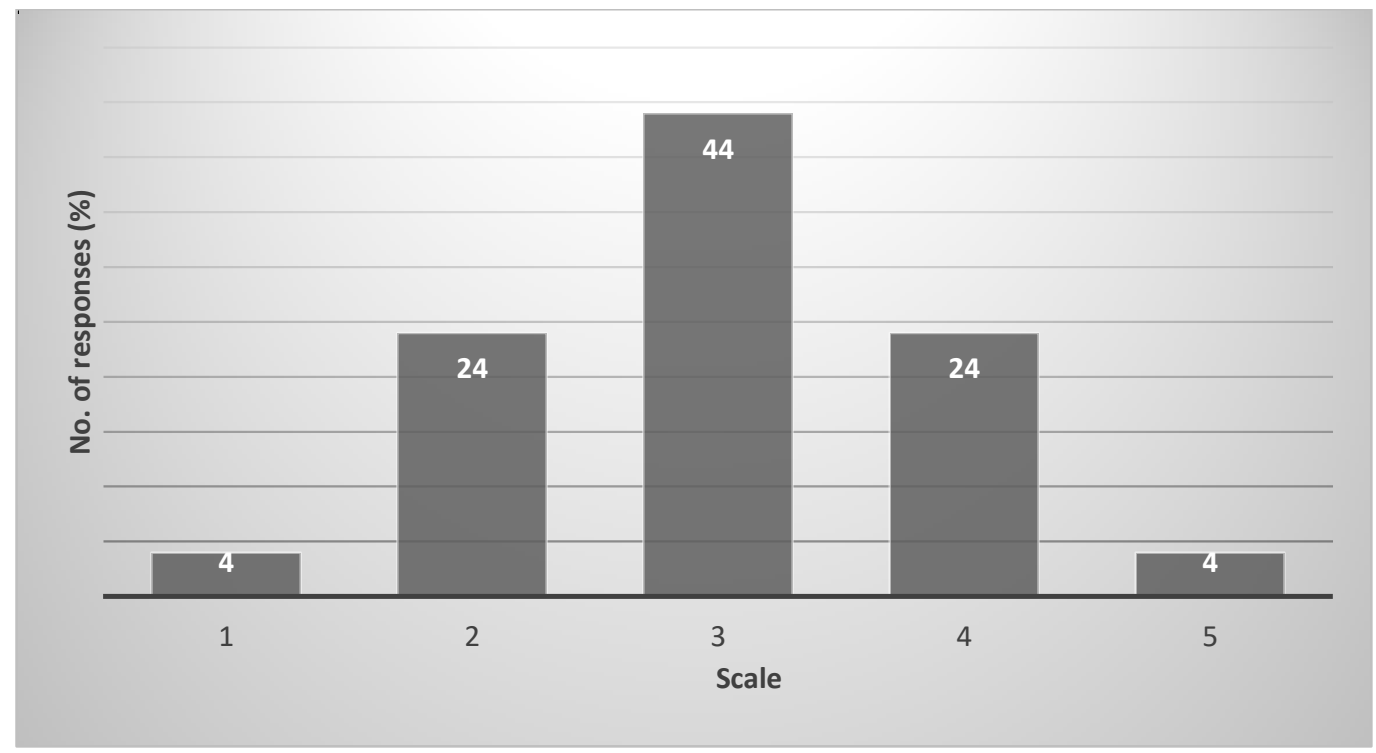

Figure 3: Response to Item 1

In item 2, participants had to view whether their students can 'interact with a degree of fluency and spontaneity that makes regular interaction with native speakers quite possible without strain for either party'. This item relates to communicative skill. The data (refer to Figure 4) show that only $12 \%$ (from scale $4 \& 5$ ) of the participants strongly agreed and agrees, while 32\% neither agreed nor disagreed, and another 56\% (from scale 1 \& 2) disagreed and strongly disagreed for item 1 . This shows that in terms of communicative ability, most students have shown that they are capable to communicate fluently and spontaneously.

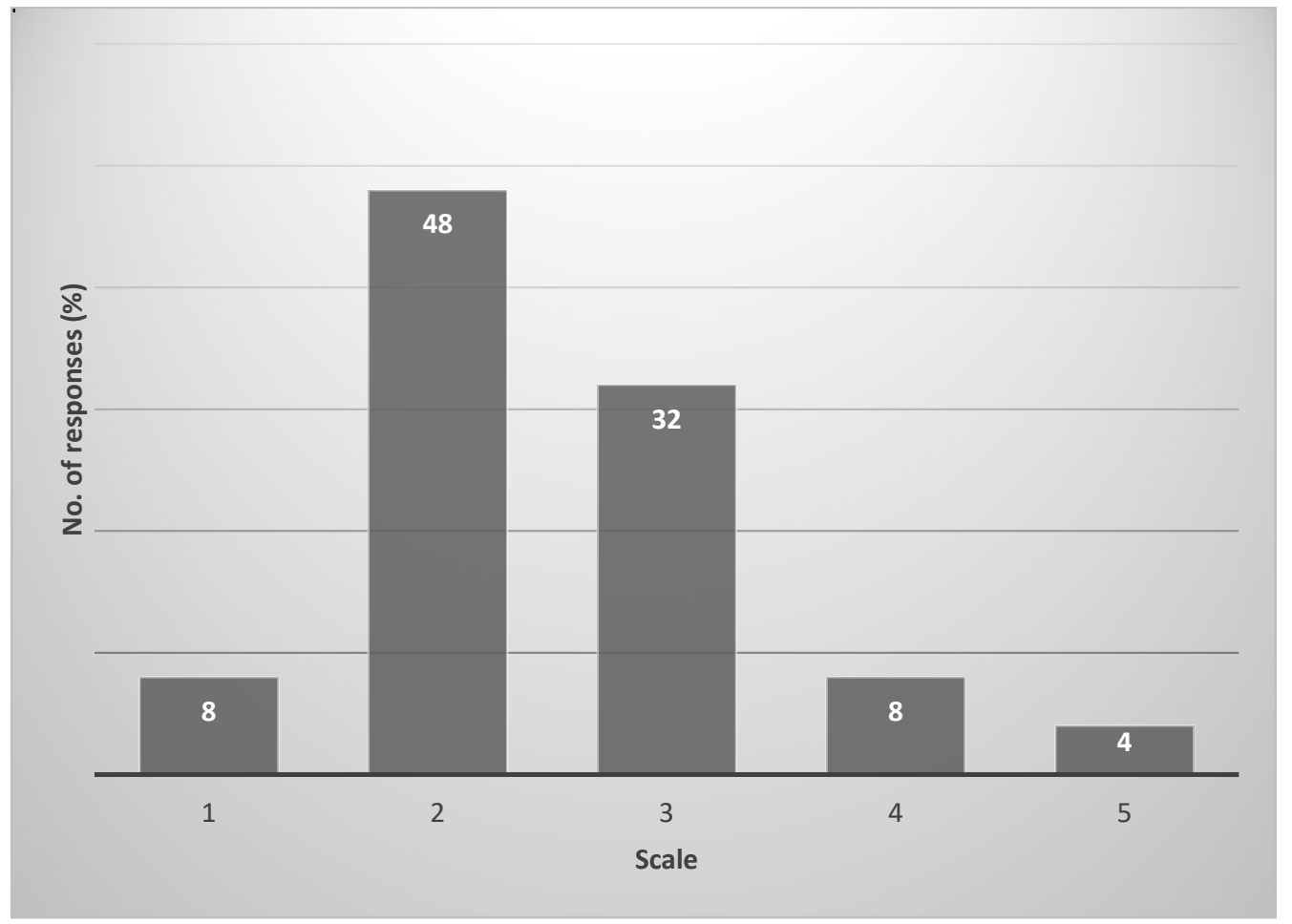

Figure 4: Response to Item 2

In item 3, participants had to view whether their students can 'produce clear, detailed text on a wide range of 
subject'. This item focuses on writing skill. The data (refer to Figure 5) show that only $8 \%$ (from scale 5) of the participants strongly agreed, while $32 \%$ neither agreed nor disagreed, and another $60 \%$ (from scale 1 \& 2 ) disagreed and strongly disagreed with item 3 . This shows that overall, many students are still unable to write clearly and on different topics.

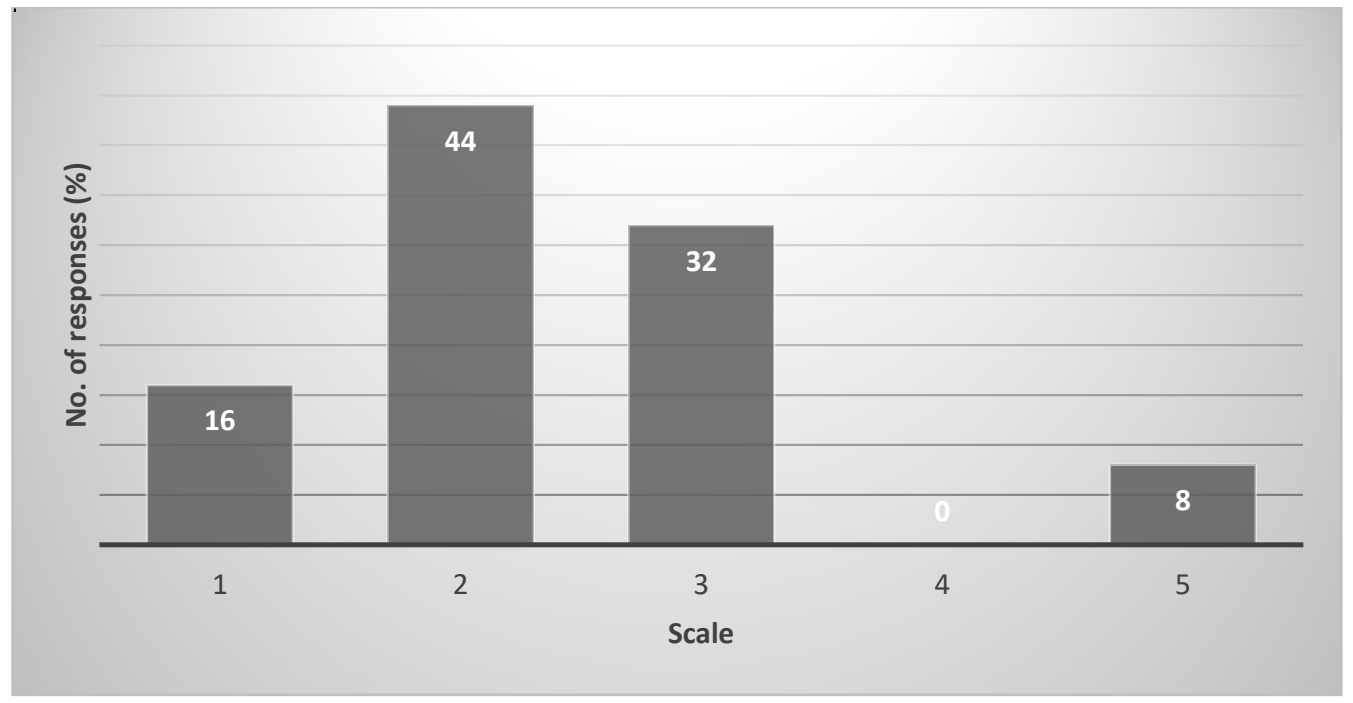

Figure 5: Response to Item 3

In item 4, participants had to view whether their students can 'explain a viewpoint on a topical issue giving the advantages and disadvantages of various options'. This item also links to communicative skill. The data (refer to Figure 6 ) show that $40 \%$ (from scale 4 \& 5) of the participants strongly agreed and agreed, while $32 \%$ neither agreed nor disagreed, and another $28 \%$ (from scale 1 \& 2 ) disagreed and strongly disagreed. This shows that most students are able to provide clear explanation on specific areas of concern.

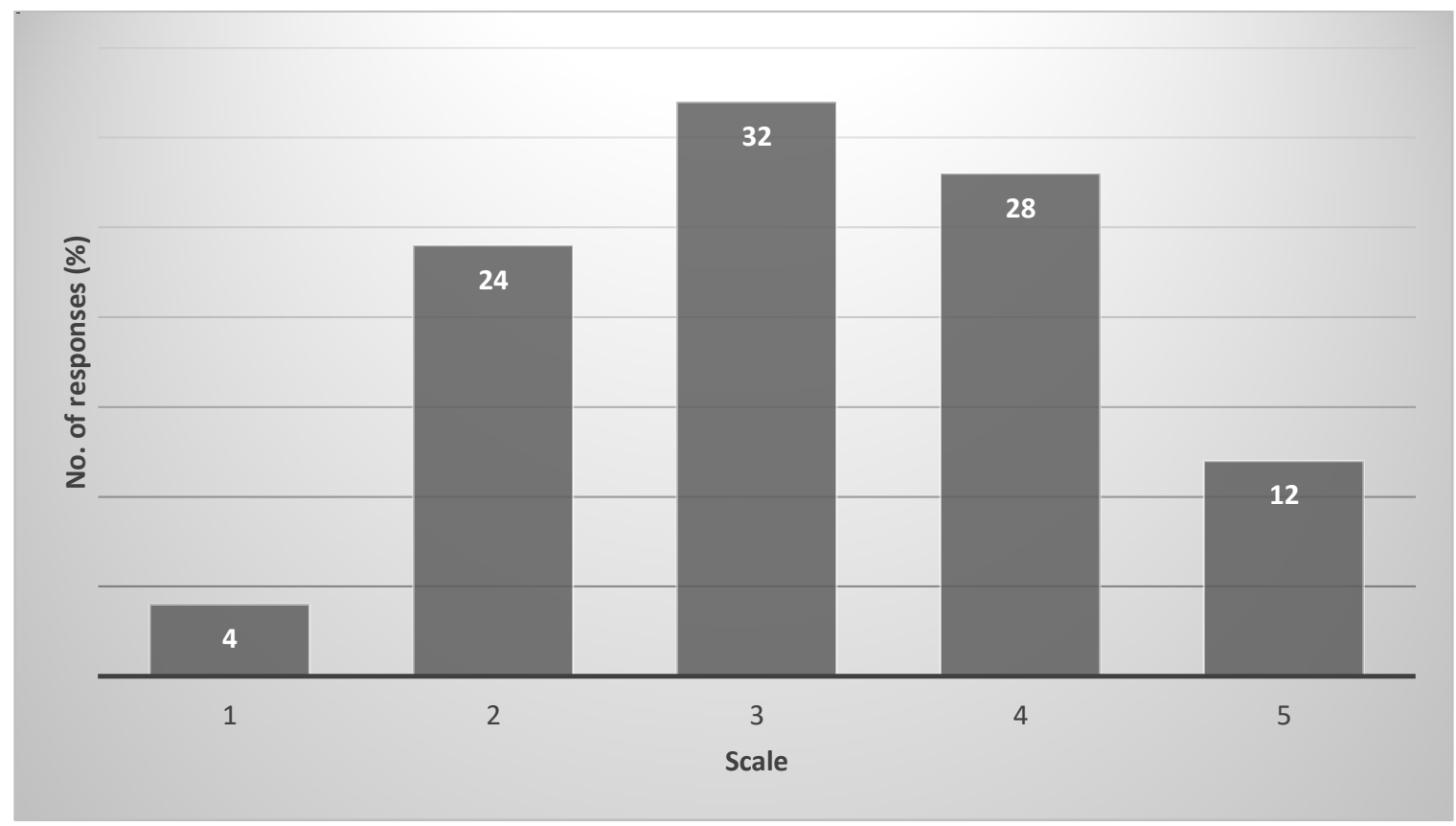

Figure 6: Response to Item 4

\section{DISCUSSION}

Data shows there are variations in teachers' views towards students' performance in English language proficiency courses, and this may not necessarily fit into the CEFR standards targeted for university learners, which is at Band 2 of CEFR global scale. Areas of concern is on reading, where a low percentage of teachers regard their students as able to understand main ideas of complex texts; and writing skill, where a very limited number of teacher feel that their students can produce clear and detailed texts. The result of this 
study acts as preliminary data for further research on the link between English language course content and CEFR standards, as well as the targeted aim of English proficiency level for university students.

\section{CONCLUSION}

Through this study, it is hoped that future design of teaching and learning materials that contribute to 'proficient' learners at the end of university years, can be developed. This would hopefully ensure that our students are globally marketable in the future. With an early analysis of the documents, it is hoped that the university will be able to revise the English language course content so that it fits into CEFR descriptors. By considering the CEFR targets of university students, which is to achieve a minimum proficiency of independent user (B2 or $\mathrm{C} 1$ ), the university can hopefully support the national aspirations that is to produce students who are highly qualified, confident and proficient in the English language. To suit the current English education transformation, the CEFR can provide a useful tool in planning the curriculum development, teaching and learning activities, and assessment at all levels of English language education to ensure the success of English language teaching and learning in universities.

\section{ACKNOWLEDGEMENTS}

This is a part of the project under The Administrative Grant Scheme (No: 13415).

\section{REFERENCE LIST}

Darmi, R., Mat Saad, N.S., Abdullah, N., Puteh-Behak, F., \& Zakaria, Z. A. (2016). Mapping English language courses to Common European Framework of Reference (CEFR) standards. Proceeding Local University Education Deans' Council Seminar.

Hamidah Yamat, Nur Farita Mustapa Umar \& Muhammad llyas Mahmood. (2014). Upholding the Malay Language and Strengthening the English Language Policy: An Education Reform. International Education Studies, 7(13), 197-205.

Council of Europe. (2001). Common European framework of reference for languages. Language Policy Unit, Strasbourg. Retrieved from http://www.coe.int/lang-CEFR.

Ministry of Education Malaysia. (2015). English Language Education Reform in Malaysia: The Roadmap 2015-2025. English Language Standards and Quality Council.

Malaysian Examinations Council. (2006). Malaysian University English Test (MUET) Regulations, Test specifications, test format and sample questions.

Ministry of Education Malaysia. (2012). Preliminary Report - Malaysia Education Blueprint Executive 20132025 Executive Summary, E-16.

Nik, H. O., Azmi, A. M., Rusyda, H. M., Arena, C. K., \& Khairani, A. A. (2012). Graduates' employability skills based on current job demand through electronic advertisement. Asian Social Science Journal, 8(9).

Pelan Pembangunan Pendidikan Malaysia 2013-2025. (2012). Putrajaya: Kementerian Pendidikan Malaysia.

Tan, K. W. (2005). The medium-of-instruction debate in Malaysia English as a Malaysian language? Language Problems \& Language Planning. Retrieved from http://www.factworld.info/malaysia/news/debate.pdf 